\title{
56. Erfahrungen mit einer neuen Unterstiitzungsnaht zur Verhinderung von Wundrupturen
}

E. Bauer, W. Priesack und K.-H. Fuchs

Abteilung Allgemeinchirurgie der Chirurgischen Universitäts-Klinik Kiel, Hospitalstraße 40, D-2300 Kiel

\section{Experience With a New Supporting Suture for Prevention of Wound Rupture}

Summary. Wound rupture of the abdominal wall is a complete dehiscence of all layers with prolabation of the intestinum. The incidence after abdominal surgery is $1-3 \%$ with a mortality rate of $20-60 \%$. The experience with a new prophylactically used supporting suture is demonstrated. With this method the incidence of wound rupture is decreased from $1.7 \%$ to $0.48 \%(P<0.01)$.

Key words: Abdominal surgery - Wound rupture - Supporting suture.

Zusammenfassung. Die Wundruptur oder der Platzbauch ist definiert als komplettes Auseinanderweichen aller Bauchwandschichten mit Vorfall des Intestinums und kommt bei $1-3 \%$ aller Abdominaleingriffe vor. Die Letalität dieser Komplikation beträgt zwischen $20-60 \%$. Erfahrungen mit einer neuen Unterstützungsnaht, die systematisch-prophylaktisch angewendet wurde, werden demonstriert. Hierdurch konnte die Incidenz der Wundruptur von 1,7\% auf $0,48 \%(P<0,01)$ gesenkt werden.

Schlïsselwörter: Abdominalchirurgie - Wundruptur - Unterstützungsnaht.

Manuskript nicht eingegangen. 